\title{
Transformatie van de zorg als city planning
}

\author{
Duco Bannink \& Eric van der Hijden*
}

De ziekenhuissluiting van afgelopen jaar in Lelystad en die van het Slotervaart in Amsterdam waren geen gepland onderdeel van de transformatie van het zorgstelsel. In het geval van Lelystad heeft de sluiting vervelende consequenties voor aanrijtijden en de bereikbaarheid van zorg. Althans, formeel is dat niet zo, maar die ervaring bestaat wel degelijk. Daar staat tegenover dat je de sluiting van het Slotervaart-ziekenhuis wel zou kunnen opvatten als een redelijk eenduidige meevaller voor de beweging naar minder ziekenhuiszorg ten gunste van meer zorg buiten het ziekenhuis en meer maatschappelijke en informele zorg.

Wij zijn in Nederland nu al zo'n twee decennia bezig met de transformatie van het zorgstelsel. Dat gaat om de veel grotere verantwoordelijkheden van de zorgverzekeraars, gemeenten en zorgkantoren, om de invoering van de Wet maatschappelijke ondersteuning, om de omvorming van de langdurige zorg, enzovoort. Er is wetgeving die deze verschuivingen voorschrijft, maar een beetje bestuurskundige en een beetje bestuurder weten dat het zo niet werkt. De wereld hangt aan elkaar van 'padafhankelijkheden'. Dat wat er is, bepaalt dat wat er kan komen. We transformeren niet in één keer, maar we bouwen voort op wat we hebben en bewegen zo hopelijk heel langzaam naar een nieuwe wereld toe.

De transformatie van een beleidsdomein inclusief de daarbij behorende organisaties en actoren en infrastructuur heeft veel weg van een proces van city planning. Onder Napoleon III sloopte Haussmann het midden uit Parijs en legde daar een stelsel van boulevards neer rond de Arc de Triomphe. Tsaar Peter huurde Nederlandse ingenieurs in en bouwde Sint-Petersburg naar Nederlands model. Dat ziet er mooi uit, maar het vereist een unitaire besluitvormer en een volgzame of zwakke sector waarover besloten wordt.

Dat hebben we niet in Nederland en dat is maar goed ook. In dat geval wordt city planning een proces waarin je als bestuurder beperkt wordt door allerlei zaken. In de eerste plaats door de gebouwen die er staan. Soms valt er eentje om en dan heb je geluk, maar dat gebeurt niet vaak. In de tweede plaats door al die maatschappelijke organisaties, bedrijven, burgers, die al dan niet op de ene of de andere plek, vanwege de ene of de andere kans of bedreiging die van elders komt, ergens een gebouw willen neerzetten, van een bepaalde functie, grootte, uitstraling enzovoort. Als ze ongeveer hetzelfde idee hadden als jij, dan heb je geluk, maar ook dat gebeurt niet vaak.

City planning is daarmee het zo voorbereiden van de 'context' dat de voorkeuren van andere actoren zich mogelijk in de richting van jouw eigen voorkeur bewegen

* Dr. Duco Bannink is redactielid van Beleid en Maatschappij. Dr. Eric van der Hijden is werkzaam aan het Talma Instituut van de Vrije Universiteit Amsterdam. 
en het gebruikmaken van kansen die zich op allerlei momenten, nauwelijks voorspelbaar (het voelt aan als toeval), voordoen.

In de bestuurskunde wordt al heel lang een onderscheid gemaakt tussen een panoptisch-rationele methode van beleidsvorming en een incrementeel model. In beide modellen wordt meer en meer het belang van maatschappelijke participatie en coproductie in de beleidsvorming en beleidsuitvoering herkend. De panoptisch-rationele methode wordt door velen als achterhaald beschouwd, maar het wordt tegelijkertijd wel degelijk toch als wenselijk model gezien door zowel bestuurskundigen als bestuurders.

In de panoptisch-rationele methode brengt een bestuurder in kaart wat 'het' probleem eigenlijk is, zet hij de opties op een rij, weegt hij de voor- en nadelen van de verschillende opties af en voert hij de voorkeursoptie stapsgewijs in. Dit vooronderstelt dat de voor- en nadelen van de verschillende opties op een rij te zetten zijn en dat er een te identificeren enkele voorkeursoplossing bestaat, dat er uiteindelijk geen gebrek aan overeenstemming is over de uiteindelijk te realiseren waarde (dat we dus allemaal uiteindelijk hetzelfde ideaalbeeld voor ogen hebben) en dat de verschillende organisaties, associaties, belanghebbenden zullen meewerken aan de invoering van de voorkeursoptie.

Hier tegenover staan modellen die niet zozeer de rationaliteit van beleidsvorming en beleidsimplementatie benadrukken, maar die juist wijzen op de kenmerken van het beleidsproces als bepalend voor de beleidsuitkomst. Beleidsprocessen worden gezien als een maatschappelijke strijd tussen verschillende normatieve voorkeuren en belangen en tussen verschillende feitelijke beelden van de werkelijkheid. Er is niet een plan van een bestuurder, maar er zweven heel veel plannen rond van allerlei actoren die pogingen doen om het geheel van het bestuur te beïnvloeden.

Als je het zo opschrijft, valt meteen de, hoe moet je het zeggen, naïviteit van het panoptisch-rationele model op. Maar aan de andere kant: iedereen die in de zorg rondloopt, of in andere domeinen waarin samengewerkt moet worden, weet dat er altijd wel iemand opstaat die zegt: 'Maar we willen toch allemaal goede zorg? We willen toch allemaal het beste voor de patiënt?' Jazeker, dat willen we allemaal, maar dat betekent toch voor iedereen net iets anders, of heel iets anders.

Neem de idee van een 'transformatie' van de zorg. Die beleidsambitie heeft een einddoel waarvan we de contouren wel min of meer kunnen vaststellen: het gaat om zorg die betaalbaar is, die minder uitsluitend medisch is en die steviger is ingebed in de maatschappelijke context en meer ruimte laat aan de eigen verantwoordelijkheid van burgers en waarin enerzijds meer ruimte bestaat om in het individuele geval maatwerk vorm te geven, terwijl tegelijkertijd meer eenduidigheid bestaat over wat voor aanpak in het individuele geval moet worden gekozen. De strofe 2-1-0 (van tweede, naar eerste naar nulde lijn) wordt veel gebruikt om de vermaatschappelijking van de zorg aan te duiden. De strofe 1-1-1 (een gezin, een plan, een regisseur) wordt vooral in het domein van de maatschappelijke zorg 
vaak gebruikt om de idee van enerzijds eenduidigheid en anderzijds maatwerk aan te geven.

De contouren kunnen we vaststellen, maar de nadere invulling van die transformatie roept meteen associaties op met city planning. Want 2-1-0 betekent versterken van de nulde lijn, maar ook ontmantelen van de tweede. En 1-1-1 betekent opbouwen van een nieuw, geïntegreerd omvattend zorgdomein, maar ook het ontmantelen van deeldomeinen.

De transformatie van het zorgsysteem is 'city planning' op nationale schaal. Soms valt er een gebouw om en kun je wat nieuws. In het algemeen ben je als planner afhankelijk van wat zich voordoet. Met de transformatie van de zorg is in dit verband iets raars aan de hand. Die leidt tot het ongepland omvallen van ziekenhuizen. Sturing richting transformatie heeft hier wel degelijk effect, namelijk dat omvallen. Het heeft echter toch kenmerken van city planning, want waar die ziekenhuizen dan omvallen is wel te voorspellen, maar moeilijk te sturen. Als je - in overeenstemming met de doelen van de transformatie van het zorglandschap - de chronische zorg uit het ziekenhuis haalt, wordt het verdienmodel voor ziekenhuizen lastig. Zonder de continue inkomsten van de chronische zorg wordt het moeilijk om ook spoedzorg te blijven geven, die draait op de overhead (het gebouw, de administratieve infrastructuur, de beschikbaarheid van het personeel) die vanuit de chronische zorg wordt bekostigd. Maar haal je de spoedzorg uit het ziekenhuis omdat kwaliteitsnormen om een grotere schaal vragen, dan haal je voor veel medisch specialisten het hart uit het ziekenhuis: wat is een ziekenhuis zonder spoedzorg? Als een city planner die moet werken met wat er is, zou je moeten kijken op wat voor manier verandering in de bekostiging, infrastructuur enzovoort de bestaande situatie beïnvloedt. De overheid zet een transformatie van de zorg in, maar lijkt veel te weinig een beeld te hebben van de manier waarop die transformatie interfereert met het bestaande systeem.

In 2018 is een belangrijke stap gezet in de zorg doordat partijen een visie hebben ontwikkeld op de inhoud van de transformatie van de zorg. De taskforce JZOJP is ingesteld naar aanleiding van het regeerakkoord van Rutte III. ${ }^{1}$ De taskforce bestond uit een breed samengestelde groep leden, waaronder patiënten, gemeenten, wijkverpleging, huisartsen, ziekenhuizen enzovoort. De taskforce publiceerde in april 2019 hun rapport met de titel De Juiste Zorg op de Juiste Plek. Het is de inhoudelijke onderlegger van de daaropvolgende hoofdlijnakkoorden per sector.

In De Juiste Zorg op de Juiste Plek staat het dagelijks functioneren van mensen centraal en dat vertaalt zich naar drie doelen: voorkomen, verplaatsen en vervangen van zorg. Het motto van 3-2-1 is vertaald naar deze drie begrippen. Door bijvoorbeeld versterking van de diagnostiek van de huisarts door medisch specialisten wordt verwijzing voorkomen als dat niet nodig is. Zo wordt directe zorg van bijvoorbeeld verpleegkundigen op een zorglocatie vervangen door bijvoorbeeld eHealth. Ook wordt behandeling van relatief eenvoudige ingrepen in een academisch ziekenhuis verplaatst naar een ziekenhuis in de buurt. Dit helpt mensen 
beter te leven en te functioneren met hun ziekte of beperking. Dit is het leidende principe achter de transformatie van de zorg.

In de uitwerking is een aantal activiteiten te onderscheiden. ${ }^{2}$ Zo worden succesvolle initiatieven in kaart gebracht met de gedachte die daarna op te schalen, worden er afspraken gemaakt over hoe partijen met elkaar samenwerken in de regio vanuit het idee dat een centrale regisseur belangrijk is, en worden regiobeelden ontwikkeld die in kaart brengen wat per regio de knelpunten zijn die aandacht vragen. Deze aanpak van de transformatie van de zorg kent zowel kenmerken van het panoptisch-rationele model als kenmerken van het incrementele model van beleidsvorming. Het is city planning waarbij wordt voortgebouwd op het bestaande, maar men zich tegelijkertijd richt op een verder liggende horizon. Wat kunnen we leren van eerdere hervormingen in het buitenland om een analyse te maken van een mogelijk volgende stap?

In het Verenigd Koninkrijk loopt het proces van transitie al enkele jaren. ${ }^{3}$ Duidelijk is dat bij het bereiken van de juiste zorg op de juiste plek het bestaande aanbod niet meer voldoet en met name ook de afstemming van zorg aandacht vraagt. De les van het Verenigd Koninkrijk is dat vier cruciale vragen te beantwoorden zijn: Welke zorg hebben we nodig? Waar wordt die geboden? Wie gaat dat leveren? En wie coördineert de zorg op individueel niveau? Het vinden van een antwoord op deze vragen is vrijwel onmogelijk in algemene zin en zeker op een landelijke schaal. In het Verenigd Koninkrijk is vanuit dit inzicht op landelijk niveau enerzijds een operationalisatie gemaakt van de doelstelling van het bieden van de juiste zorg op de juiste plek, en anderzijds is bepaald welke organisaties betrokken zijn en wat globaal de richting van de benodigde aanpassingen is. Een vertaling naar de Nederlandse context kan zijn om de zogenaamde 'transitie' van de aanpassing van de harde infrastructuur van de zorg te onderscheiden van de 'transformatie' van de aanpassing van de zachte kant van de daadwerkelijke uitvoering van de zorg. In de transitie moeten we bepalen wie regionaal leidend is, wie welke budgetten krijgt en wie welke rol in de uitvoering van de zorg. De transformatie die daaruit moet voortvloeien gaat dan om een verandering van het gedrag van burgers en professionals, de cultuur bij zorginstellingen en de daar werkende professionals, en andere werkwijzen in de samenwerking tussen subdomeinen in de zorg. Als zo de eerste drie vragen zijn beantwoord (wie, wat, waar), is de coördinatie van de individuele zorg van cruciaal belang: de veronderstelling blijkt onterecht dat als instellingen en financier afspraken maken over wie wat doet bij het voorkomen, verplaatsen en vervangen van zorg, het dan wel goed komt. Juist bij kwetsbare groepen of chronische patiënten is er meer nodig: iemand moet zijn verantwoordelijkheid nemen om de route in het vernieuwde zorglandschap te bewaken, is de les van de National Health Service. Wie dat doet, kan verschillen en dat is de tweede les.

Dat vraagt nogal wat van gemeenten, maar vooral van de zorgverzekeraars en zorgkantoren in Nederland, en wellicht meer dan waartoe zij in de huidige context in staat zijn. Zij moeten een stevig op de regio toegespitst beleid voeren, maar tegelijkertijd een regulier landelijk inkoopbeleid vormgeven. Er zijn allerlei 
initiatieven in het land waarin een transitie van financiële en regulatieve verhoudingen wordt voorgesteld die moet bijdragen aan transformatie, maar het overzicht ontbreekt en het is lang niet altijd duidelijk hoe die initiatieven zich verhouden tot de doelstellingen van de grotere transformatie van het zorgstelsel. Weliswaar is de transformatie van de zorg als grote, panoptische operatie ingezet, de feitelijke uitwerking ervan ziet er veel meer uit als city planning, waarbij de zorgorganisaties op de werkvloer van het zorgstelsel hun eigen transities en transformaties vormgeven en doorzetten. Veel voorbeelden inventariseren van lokaal succesvolle initiatieven kan inspirerend zijn voor andere regio's. Maar de vraag van de toepasbaarheid van die initiatieven in andere regio's of zelfs de wenselijkheid ervan is niet beantwoord. Dat vraagt niet om voorbeelden, maar om leren!

In het Verenigd Koninkrijk is daarom veel aandacht voor leren van elkaar, maar hoe doen ze dat daar dan? Er worden regionale projecten expliciet geanalyseerd op de zorgfuncties die georganiseerd zijn als alternatief voor de gangbare zorg. Vervolgens leren regio's van elkaar doordat ze deze zorgfuncties herkennen en lokaal, passend op de situatie inrichten. In deze aanpak wordt dus een balans gevonden tussen lokaal maatwerk en landelijke kaders. Zo'n aanpak kan ook in Nederland werken. Het landelijke doel dat de taskforce JZOJP formuleerde, de doelstelling van de juiste zorg op de juiste plek, is daarbij echter te abstract om lokaal richting te geven. De zorgverzekeraars en zorgkantoren zouden een visie moeten formuleren op de transitie die nodig is om de transformatie naar de juiste zorg op de juiste plek te organiseren. Beoordeling van zorgconcepten vanuit zo'n visie maakt het potentieel mogelijk om die heringerichte zorgfuncties op te schalen en nader uit te werken. Die stap moet nog gezet worden, omdat de hoofddoelstelling van voorkomen, verplaatsen en vervangen nog te weinig is uitgewerkt en regio's te veel verschillen van elkaar. Op dit moment staat de analyse van de verschillen centraal door de ontwikkeling van regiobeelden. De volgende stap is een stevige analyse van de verschillende functies in de zorg en de manier waarop die in de verschillende regio's zouden kunnen worden georganiseerd. Door een overzicht van in iedere regio benodigde functies wordt 'voorkomen, vervangen, verplaatsen' concreter en is lokaal leren van andere regio's beter mogelijk. Het 'wat' is dan duidelijk. Daarna is er aandacht voor het 'hoe'. Veronderstellen dat lokaal succesvolle projecten online zetten voldoende is voor opschalen, is te mechanistisch. Maak dus een onderscheid tussen welk vraagstuk die projecten hebben opgelost (het 'wat') en hoe ze dat hebben gedaan. Dan kunnen partijen lokaal variëren op het 'hoe' om zo tot een succesvolle transitie en transformatie te komen.

Hoe toepasbaar is dit model in Nederland? Zijn functies echt goed te onderscheiden in de zorg? In het andere stuk in dit Dossier start Wink de Boer, arts en voormalig bestuurder in het Bernhoven-ziekenhuis, vanuit het uitgangspunt dat je de transformatie van de zorg inderdaad kunt zien als nauwelijks planbare 'city planning' op nationale schaal. Een visie op de zorg is nodig om in zo'n sterk padafhankelijk systeem toch tot verandering te komen. Hij werkt een visie uit op de ziekenhuiszorg, waarbij hij betoogt dat die bestaat uit vier verschillend te orga- 
niseren zorgfuncties. Deze visie is een deel van de puzzel. Een vergelijkbare analyse is wenselijk op de eerste lijn, waarbij de vraag centraal staat welk soort functies daar nodig is. Belangrijk discussiepunt van het artikel van Wink de Boer is of voor één functie, namelijk de acute zorg, een centrale planning nodig is, terwijl bij de andere juist een decentrale effectiever is.

Wetenschappers kunnen een belangrijke rol spelen bij het bereiken van de mooie ambitie van de juiste zorg op de juiste plek. In onze visie is een bijdrage aan nadrukkelijk onderscheiden van het 'wat' van het 'hoe' in de transitie een belangrijke stap in het verbeteren van de condities waarin regio's van elkaar kunnen leren.

\section{Noten}

1 www.rijksoverheid.nl/documenten/rapporten/2018/04/01/de-juiste-zorg-op-dejuiste-plek.

2 www.dejuistezorgopdejuisteplek.nl.

3 www.england.nhs.uk/new-care-models/about/. 